\title{
Die invloed van enkele strominge en lewensbeskouinge op die ontwikkeling van teorie oor Onderwysbestuur
}

\author{
P.J. Mentz \\ Skool vir Nie-formele Onderwys \\ Potchefstroomse Universiteit vir $\mathrm{CHO}$ \\ POTCHEFSTROOM \\ E-pos: doppjm@puknet.puk ac.za
}

\section{Abstract \\ The role of certain directions and life perspectives in the development of theory in Educational Management}

\begin{abstract}
In Educational Management, as in all scientific disciplines, a number of directions and life perspectives contribute to the formulation of theory in the field In this article the influence that some of these directions and life perspectives have had on Educational Management is analysed. The role and place of a Christian perspective is then described.

The directions and life perspectives which will be discussed include positivism, post-positivism and post-modernism. Vedantic and Chinese perspectives on management are then discussed, as these two perspectives represent strong underlying religious beliefs. The article closes with a Christian perspective on Educational Management and leadership - a perspective which includes guidelines for educational leaders on the way in which a Christian approach can be developed and sustained.
\end{abstract}

\section{Inleiding en historiese posisionering}

Onderwysbestuur, as selfstandige deeldissipline van die Opvoedkunde word, soos alle ander dissiplines in die wetenskap, gekenmerk deur 'n verskeidenheid strominge. Die breěr strominge in die wetenskap, waaronder die positivisme, postpositivisme en postmodernisme het op ' $n$ verskeidenheid maniere neerslag gevind in die Onderwysbestuur. Alhoewel daar 'n verskeidenheid strominge is waardeur teoriebou in die wetenskap beinvloed word, word in dié artikel 

Onderwysbestuur het.

Waar die debat in die verlede gewentel het rondom die aard en wese van administrasie en bestuur, het Onderwysbestuur in 'n fase van kritiese ondersoek inbeweeg. Hierdie fase word gekenmerk deur eksplisiete standpuntstellings ten gunste van pragmatisme (Hoy, 1996) en postpositivisme (Evers \& Lakomski, 1996) as metodes van ondersoek en oproepe tot die erkenning van waardes (Begley, 1996) en 'n Christelike benadering (Thom, 1996) tot Onderwysbestuur. Outeurs skroom nie om hulleself binne 'n bepaalde kader te plaas en vanuit hierdie hoek standpunt in te neem en kritiek te lewer nie.

In hierdie artikel word, in aansluiting by die siening van Wolters (1992:1), 'n geintegreerde benadering gevolg met betrekking tot die siening van 'n teorie, 'n raamwerk en 'n lewensbeskouing. Daar word dus nie gepoog om die begrippe verwyder van mekaar te sien nie. Ouweneel (1992:5-10) noem 'n wetenskaplike teorie ' $n$ bepaalde denkwyse oor die verskynsel(s) onder beskouing. Daar word dus nie kunsmatig 'n onderskeid en klassifikasie gemaak van postmodernisme as lewensbeskouing (en/of teorie) of andersom van 'n Christelike perspektief as slegs 'n lewensbeskouing nie. Hierdie artikel het dus ten doel om 'n oorsigtelike beeld te gee van denkwyses in die Onderwysbestuur deur gebruik te maak van 'n omvattende literatuurstudie.

Die vrae wat in hierdie artikel aan die orde gestel word, wentel rondom die rol en invloed van die belangrikste denkwyses in Onderwysbestuur en die rol en plek van 'n Christelik-gefundeerde siening van Onderwysbestuur.

\section{Die positivisme}

Die grondlegger van die positivisme was Auguste Comte wat volgens die "driestadia-wet" die ontwikkeling van die mensheid en menslike denke uiteengesit het. Hiervolgens deurloop menslike ontwikkeling drie stadia: die teologiese stadium, waarbinne wetenskaplike verskynsels in terme van een of ander bo-natuurlike entiteit verklaar word; die metafisiese stadium, waar gesoek word na die wese van dinge binne die werking van onderliggende kragte en die positiewe stadium, wat as die wetenskaplike fase bekend staan en wat empiries waarneembare feite aanvaar as die enigste riglyn vir wat waar en wetenskaplik is (Botha, 1990:4546).

Positivisme word deur Raath (1988:349) beskou as 'n wetenskap wat die verskynsels in die werklikheid kan ondersoek sonder om 'n beroep op die feite te doen wat nie deur die menslike ervaring gestaaf kan word nie. Romm (1991:2) brei hierop uit wanneer hy positivisme definieer as empiriese dissipline waarvan alle kennis op empiries observeerbare feite gegrond is, waarby Botha (1990:46) 
aansluit deur te sê dat die "werklikheid" deur die positivisme beskou word as dit wat vir die sintuie toeganklik is.

Op grond van hierdie empiries waarneembare kennis kan voorspellings gemaak word wat spesifieke resultate verbind met spesifieke omstandighede. Binne die kader van die positivisme word voorspelling moontlik gemaak deur hipotesestelling wat as belangrike deel van die wetenskaplike proses erken word en sintuiglike waarneming as die enigste basis waarop ware kennis gebaseer kan word. Waarneming kan egter nie plaasvind alvorens 'n voorafgaande teorie ontwikkel is wat die waarneming kan rig nie. Teoretiese spekulasie en sintuiglike waarneming moet dus voortdurend gekombineer word (Romm, 1991:15). Daar bestaan volgens Romm (1991:21-23) drie basiese waarnemingsmetodes wat deur die positivisme gebruik word, naamlik direkte observasie (binne natuurlike omstandighede), eksperimentering (binne kunsmatige omstandighede) en die metode van vergelyking.

Positivisme behels volgens Ouweneel (1992:24) die opvatting van 'n "neutrale, objektiewe wetenskap" wat uit die waaneming van "objektiewe feite" sekere teorieë aflei wat dan deur daaropvolgende waarnemings "geverifieer" moet word. Waardeoordele hoort volgens Botha (1990:47) nie binne hierdie objektiewe wetenskap tuis nie, aangesien dit geen wetenskaplike geldigheid besit nie

Volgens Willower (1996:346) verwys positivisme binne die onderwysbestuursteorie na 'n tydperk tussen 1950 en 1970 toe geglo is dat skole ondersoek moet word aan die hand van waarnemings, idees en metodes van ontwikkelde, relevante en empiries-toetsbare gegewens om positiewe verandering in die onderwys mee te bring. Volgens Willower het daar egter ook in hierdie tyd, in reaksie teen die positiviste 'n "eklektiese empirisme" ingetree, wat beteken dat die wetenskaplike hom/haar nie deur een enkele teorie, die positivisme, laat voorskryf het nie.

Die logiese positivisme, as stroming van die positivisme, word deur Jangam (1970:2) beskou as 'n logies-linguïstiese benadering tot die natuurlike en sosiale wetenskappe. Dit verwys eerder na 'n houding as 'n geloof en ontwikkel kennis deur die analise en spesifisering van geskrewe en gesproke taal. Die volgende kenmerke van die logiese positivisme word deur Jangam (1970:11) geïdentifiseer:

- Kennis is kenbaar in sover dit uitgedruk kan word.

- Natuurlike en sosiale wetenskappe kan effektief bestudeer word deur middel van die logies-linguistiese benadering.

- Die basis van kousaliteit en induksie word bevraagteken.

- Emotiewe aspekte soos metafisika, etiek en tradisionele filosofie is betekenloos. 
- Die tradisionele rol van filosofie as 'n wetenskap word gereduseer tot 'n wetenskap van taalanalise

Omdat die positivisme en logiese positivisme vereis dat slegs dit wat empiries waarneembaar is as wetenskap aanvaar kan word, kan die wetenskap geen waardeoordele vel nie. Die bestaande orde binne die samelewing (die waarneembare orde) moet dus positief gewaardeer word. Dit beteken dat wetenskaplikes uit die positivistiese skool - volgens Botha (1990:56) - nooit mag vra hoe die gemeenskap behoort te wees nie, nooit mag kritiek lewer op die bestaande orde nie, maar dit onteenseglik as die enigste werklikheid aanvaar. MacPherson (1996:3) sien 'n verdere invloed van die positivisme in Onderwysbestuur veral op die terrein van leierskapsteorieë. 'n Verskeidenheid teorieë oor leierskap het te doen met die "plasing" van die leier binne 'n bepaalde "ruit" op grond van resultate wat behaal is na die voltooiing van 'n "objektiewe" meetinstrument. Die leier behaal 'n sekere punt vir byvoorbeeld taakoriëntasie en mensoriëntasie en word dan geklassifiseer as laag-laag, laag-hoog, ensovoorts. Die poging om empiries waarneembare feite as enigste basis van beoordeling te gebruik en menslike optrede te bepunt, is duidelik

Positiviste glo onwrikbaar in die waarde van feitelike, empiriese inligting. Hierdie geloof word weerspieël in leierskapsteorieë waarin slegs gefokus word op die meetbare faktore rondom insette, prosesse en uitsette soos deur die leier gebied. Die leier as mens, sy behoeftes, asook dié van sy ondergeskiktes, word geensins in ag geneem nie.

\section{Die postpositivisme}

Die verset teen die positivisme, veral teen die logiese positivisme, kan volgens Botha (1990:61) nie met slegs een skool in die wetenskapsfilosofie geassosieer word nie. Die Historiese Skool kan egter as baanbrekers van die postpositivistiese era beskou word. Hierdie filosofiese wetenskap het die klem, in teenstelling met die positivisme, baie sterk op die geskiedenis van die wetenskap laat val, in 'n poging om die dinamiek van verandering binne die wetenskap te verklaar.

Die wetenskap word deur postpositiviste nie meer beskou as 'n objektiewe empiries waarneembare stel feite nie, maar word voorgestel as iets wat nooit neutraal kan wees nie. Die verkeerdelike, dualistiese skeiding tussen feite en waardes en tussen kennis en geloof moet tersyde gestel word vir 'n meer integrale beskouing van die wetenskap (PU vir CHO, 1996:99). Vooronderstellings speel in alle wetenskaplike teorieë 'n deurslaggewende rol. Die betekenis van alle wetenskaplike terme, asook die vrae wat as geldig binne die wetenskap aanvaar word, word dan ook deur hierdie vooronderstellings (paradigmas) bepaal (Botha, 1990:62) 
As stroming van die postpositivisme stel Hoy (1996:370) as onderwysbestuurskundige die pragmatiese perspektief voor. Kennis is hiervolgens die produk van sistematiese ondersoek wat onderlê word deur teorieë en is onderhewig aan openbare prosedure. Soos nuwe kennis ingewin word, kan bestaande teorieë verwerp word om plek te maak vir meer relevante teorieë Onderwysbestuurders wat toegang het tot konsepte en basiese beginsels van organisasie beskik dus reeds oor die nodige instrumente om observasie, interpretasie en konstruksie van nuwe teorieë moontlik te maak.

'n Tipiese postpositivistiese metodologie word deur Robinson (1996:429-431) voorgehou wanneer hy 'n probleemgebaseerde metodologie vir Onderwysbestuur voorstel. Hy beweer dat bestaande bestuursbeleid en -praktyk die oplossings is van probleme uit die verlede. Hierdie oplossings is na verloop van tyd nie altyd meer relevant nie. Die probleemgebaseerde metodologie verskaf ' $n$ teorie wat die aard van 'n probleem ondersoek en definieer aan die hand van ' $n$ bepaalde vooronderstelling. Dan word kriteria verskaf waaraan die toereikendheid van moontlike oplossings vir hierdie probleem gemeet kan word. Kritiese dialoog tussen die betrokkenes is van die uiterste belang om die relevansie en bruikbaarheid van die probleemoplossings te bepaal. Kriteria om die toereikendheid van die oplossing te bepaal sluit onder andere die volgende in: die effektiwiteit van die oplossing om aan spesifieke vereistes te voldoen, samehangendheid van die oplossing, en bewys dat die probleem op so 'n manier geformuleer is dat dit moonlik is om die tekortkominge daarvan te identifiseer en dan reg te stel.

Thom (1996:10) beskryf 'n postpositivistiese onderwysleierskapsmodel waarbinne 'n algemene milieu teenwoordig is waarin die onderwysleier ' $n$ subjektiewe respons kan lewer op die gesamentlike behoeftes en begeertes van die verskeie onderwysgroepe onder sy beheer. Die hoofkomponente van hierdie model kan soos volg saamgevat word:

- Leierskapsgedragsvlakke van die eerste vlak (roetine) en van die tweede orde (playing hardball) word geïdentifiseer: eersteorde-aktiwiteite beïnvloed bevrediging en genot van take; tweedeorde-aktiwiteite behels die neem van risiko's en dit gaan dikwels gepaard met stres, frustrasie en kompetisie.

- Onmiddellike en langtermyntydsraamwerke word geïdentifiseer: binne 'n langtermynraamwerk word die werklike waarde van die leier en die onderwysinstansie bepaal; hier word ook verwys na die morele inslag van die organisasie en die individu. Binne hierdie raamwerk word betaal vir swak besluite wat geneem is op bogenoemde gedragsvlakke.

- Universele uitgangspunte van wat reg en regverdig is, vorm die basis van hierdie model: om dus effektief te wees, moet die onderwysleier hierdie eienskappe vertoon. 
'n Ander postpositivistiese benadering tot onderwysleierskap word deur Gronn en Ribbens (1996:454-458) verskaf. Hierdie benadering wil die belangrikheid van die konteks van leierskap benadruk. Binne tradisionele leierskapsteorieë word nie genoegsame aandag gegee aan die mense wat die leierskapsposisies beklee nie. Etnografiese en biografiese metodologiese benaderings kan gebruik word in die studie van leierskap om bogenoemde tekortkominge te minimaliseer en om die konteks waarbinne leierskap plaasvind, korrek te tipeer. Tradisionele gebruik van vraelyste het die kulturele, kognitiewe en affektiewe raamwerke van die "proefpersone" verlore laat gaan. Hierdie blatante positivistiese ignorering van die proefpersone se verwysingsraamwerke het gelei tot ongeldige afleidings uit die versamelde data.

\section{Die postmodernisme}

Postmodernistiese denke weerspieël 'n analise van taalgebruik, aangesien taal hiervolgens direk in verhouding staan tot sosiale mag. Maghebbendes binne 'n gemeenskap beheer die "ondergeskiktes" binne die gemeenskap deur middel van indoktrinasie en dominering van die linguale konteks waarbinne geregeer word. Die persoon met die sterkste argument het volgens Foster (1993:8) die beste kans om 'n magsposisie binne die gemeenskap te beklee.

Volgens Gitlin (aangehaal in Fourie, 1993:3) het vier belangrike tendense 'n invloed uitgeoefen op die ontwikkeling van die postmodernisme:

- Multinasionale kapitalisme (eie tradisies, waardes en geskiedenis word deur internasionale waardes oorskadu).

- Historiese diskontinuïteit (die wêreldgeskiedenis verloop nie volgens 'n lineêre orde nie)

- Die yuppie-generasie (postmoderniste is gewoond aan diskontinuïteit en 'n vryemarkstelsel wat 'n eindelose bron vervangbare ware bied).

- Die Amerikaanse kultuur (veral ten opsigte van die jukstaponering van verskillende kulture, tale, gelowe, lewens- en wêreldbeskouings).

Die postmodernisme stel dat daar subtiele politiese en kulturele vooroordele bestaan wat die wetenskap beheer. Die wetenskap word dus beskou as behorende tot die dominante sosiale klas binne 'n bepaalde gemeenskap. Taal en idees is hiervolgens instrumente vir onderdrukking - die maghebbendes praat vir die massas (Willower, 1996:357).

Foster (1993:12-13) identifiseer drie historiese periodes in die geskiedenis van bestuur waarvan die postmodernisme deel uitmaak: 
- Romantiese periode: die mens is die primêre krag agter alle georganiseerde aktiwiteit; bestuurders moet dus sensitief wees vir die behoeftes van die mense binne die organisasie.

- Modernistiese periode: klem word gelê op die rede en die krag van waarneming; mense beskik oor die rasionele vermoë om hul "toekomsbestemmings" te beheer deur middel van die toepassing van sowel wetenskaplike as tegnologiese hulpmiddels.

- Postmodernistiese periode: daar bestaan geen basiese struktuur vir kennis nie; alle mense streef mag en invloed na; deur middel van taal word die magsposisie van die gemeenskap beskryf.

Laasgenoemde benadering tot kennis wil beklemtoon dat alleen deur middel van taal en gesprek die leiers in 'n gemeenskap die "ware" beeld van die gemeenskap en die sosiale verhoudinge daarbinne kan weerspieël. Konseptuele taalgebruik word dan ook verwerp ten gunste van meer ekspressiewe, metamorfiese taalgebruik om kulturele voorkeure uit te druk (Foster, 1993:4, 10). Aangesien omstandighede tyds- en plekgebonde is, gaan die kennisbasis van elke situasie verskil. Bestaande konkrete kennis is dus volgens Foster (1993:7) in werklikheid slegs kennis relevant tot 'n spesifieke situasie waarvan die parameters gedefinieer word deur die betrokke geskiedenis en kultuur.

Buiten mondelinge verteenwoordiging identifiseer Foster (1993:9-11) nog drie aspekte wat eie is aan die postmodernisme, naamlik orde, metafisika en geskiedenis. Wat hul beskouing van orde betref, glo die postmoderniste dat die ooglopende, natuurlike sosiale orde binne 'n gemeenskap die moontlikheid van die bestaan van ander "ordes", wat ook deel uitmaak van die sosiale struktuur, verberg; hulle verwerp dus natuurlike orde. Vir hierdie denkrigting staan geskiedkundige gebeure ook in 'n geringe of geen verhouding tot mekaar nie; geskiedenis reflekteer eerder 'n reeks gebroke, onafhanklike verskynsels. Geskiedenis word dan ook nie beskou as die vooruitgang van universele rede nie, maar wel as ' $n$ magspel waar die mens met verloop van tyd van een dominerende party na 'n volgende beweeg. Die onderwysbestuurder kan dan ook slegs sy taak volledig uitvoer as hy die "storie" van menslike dominering en strewe na mag en beheer verstaan.

'n Vaste organiserende raamwerk word deur die postmodemisme verwerp. So 'n raamwerk word beskou as bloot tydelik van aard en verteenwoordigend van die spesifieke belange van die maghebbende faksie binne 'n sosiale konteks - 'n raamwerk wat binne 'n bepaalde "verhaal" uitgespreek word (Burger, 1994:60). Postmodemistiese verhale of stories is gefragmenteerde sameflansings wat geen kontinuiteit (storielyn) voorstel nie, en ook nie op 'n logiese gevolgtrekking uitloop nie. Elke fragment word binne 'n bepaalde konteks geplaas; 'n konteks 

is ook al beskryf as ' $n$ veelheid van verskynsels

Postmodernisme in die Onderwysbestuur verkondig volgens Willower (1996:346) as't ware die noodsaak van anti-wetenskaplike metodes om die effektiwiteit binne enige veld van ondersoek te verhoog. Die basiese aannames van moderne sosiale wetenskappe word in twyfel getrek, en bestaande kennis van tradisionele standaard organisatoriese teorieë word verwerp. Alle idees word deur die postmodernisme beskou as produkte van subjektiewe interpretasie en dominering of indoktrinasie (Hoy, 1996:368). Differensiasie, die verwerping van sentraalgesetelde outoriteit en die hiërargiese orde is volgens Fourie (1993:7-8) kenmerkend van die postmodernisme. Die soeke na eenheid in enige verskynsel word verwerp, en daar word geglo dat enigiets met enigiets anders gejukstaponeer kan word. Die roekelose vermenging van genres is dus 'n algemene verskynsel

Evers en Lakomski (1996:390), welbekende onderwysbestuurfilosowe, kom tot die gevolgtrekking dat die postmodernisme geen fundamentele kennisbasis vir die wetenskap aanvaar nie en dat daar geglo word dat dit onmoontlik is om die realiteit te verteenwoordig. Hierdeur word die positivisme of empiriese wetenskap verkeerdelik vereenselwig met die beoefening van die wetenskap self, wat veroorsaak dat die wetenskap dus verwerp word omdat positivisme verwerp word.

Foster (1993:14-15) verskaf die volgende implikasies van die postmodernisme vir Onderwysbestuur:

- Die wyse en metode waardeur opvoedkundige administrateurs opgelei, geselekteer en gesertifiseer word, word bevraagteken. Die idee dat fundamentele vaardighede geïsoleer en aangeleer kan word om 'n bepaalde kennisveld te beskryf, word deur die postmodernisme afgemaak as 'n ideologie om bepaalde sosiale groepe buite 'n professie te hou.

- Hierdie siening het noodwendig 'n bepaalde invloed op die opleidingsmetodes van potensiële onderwysleiers en -administrateurs, asook op die navorsingsmetodes binne hierdie velde.

- Tradisionele opleidings- en navorsingsprogramme aanvaar die bestaan van 'n fundamentele kennisbasis waarvolgens hierdie programme gestruktureer word. Die postmodernisme glo dat alle kennis konteksgebonde is en dus volgens gedifferensieerde metodes geïnterpreteer moet word

- Teorie en praktyk moet as onlosmaaklik beskou word. Hierdie uitgangspunt impliseer dat die teoretiese opleiding van onderwysleiers hulle nie nood- 
wendig kan voorberei op die hantering van elke probleem indien elke probleem konteksgebonde is nie.

\section{Enkele lewensbeskoulike perspektiewe op Onderwysbestuur vanuit 'n nie-Christelike perspektief}

\subsection{Motivering}

Dit word algemeen aanvaar dat sekere Oosterse perspektiewe die denke oor bestuur sterk beinvloed. Die kerngedagtes van lojaliteit en toewyding aan die maatskappy en inrigting as allesoorheersend het reeds in die sewentigerjare neerslag gevind in byvoorbeeld die sogenaamde Japannese bestuursteorieë. Twee aanverwante Oosterse strominge word vervolgens kortliks toegelig.

\subsection{Hindoeïsme: die Vedantiese perspektief}

Volgens Sapre (1996:3) verwys Vedanta na "a body of knowledge about the individual self, the external world in relation to oneself and about God, whose manifestation is found in creation itself'. Die Vedanta is saamgevat in 'n historiese Indiese dokument en die fokus hiervan in die moderne bestuursveld is die bestuur van "ander". Die Vedanta verduidelik dat 'n persoon homself eers goed moet ken en verstaan alvorens hy kan poog om ander effektief te lei en te bestuur.

Daar bestaan 'n groot ongelykheid tussen die opleiding van bestuurders as vaardige winssoekers en die opleiding van bestuurders met vaste waardesisteme waarop besluitneming gebaseer kan word. In die Vedantiese filosofie word volgens Desai (1996:7) geglo in die ingebore potensiaal van alle mense en in die inherente waardesisteme waarvolgens menslike handeling gerig word.

Elke mens beskik oor die vermoë om keuses te maak. Hierdie seleksievermoë is die oorsprong van elke menslike handeling. Mense handel egter nie net volgens hul keuses nie, maar reageer ook op die keuses van ander. Hierdie reaksies is gewoonlik impulsief en emosioneel van aard en kom herhaaldelik voor (Sapre, 1996:4). 'n Verantwoordelike, effektiewe onderwysleier kan onderskei tussen aksie en reaksie. Menslike gedrag word gerig deur kennis en persoonlike waardes wat op vier vlakke manifesteer: instinktiewe, geprogrammeerde gedrag, impulsiewe, emosionele gedrag, daadwerklike, beplande gedrag en spontane, karakteristieke gedrag (Sapre, 1996:5).

Wanneer 'n onderwysleier homself en sy ondergeskiktes in "Vedantiese lig" bejeën, sal die werkers onbewustelik groter insette lewer om die onderwysleier tevrede te stel. Volgens Desai (1996:8) sal so 'n ingesteldheid noodwendig tot hoer produktiwiteit in die onderwys aanleiding sal gee. Elke handeling wat die 
onderwysbestuurder uitvoer, het bepaalde gevolge. Die mens het wel beheer oor sy gedrag, maar nie oor hierdie gedragsgevolge nie. Die onderwysbestuurder kan sekere verwagtinge stel insake moontlike gevolge, maar die realiteit voldoen nie altyd aan die gestelde verwagtinge nie - nie eens binne 'n beheerde bestuursomgewing nie (Sapre, 1996:5).

Strominge in die onderwysbestuur binne die Vedanta stem grootliks ooreen met dié van Westerse denkrigtings. Die Vedantiese benadering wil ook beklemtoon dat dit nie noodwendig intellektuele vermoe is wat die effektiwiteit van 'n bestuurder bepaal nie, maar dat emosionele intelligensie wat selfbewustheid, impuisbeheer, empatie, integriteit en selfmotivering behels, ook 'n bepalende rol speel in die mate van bestuursukses

Binne die Vedantiese leer word geglo dat die hiërargiese orde binne 'n formele organisasie beskou moet word as 'n deel van die wêreld se natuurlike orde. Hoe hoër ' $n$ persoon in die hiërargiese orde funksioneer, oor hoe meer mag beskik daardie persoon. Hierdie mag is egter slegs geregverdig indien dit spruit uit die persoon se intrinsieke vermoëns en persoonlike kwaliteite. Leierskap en hierargiese orde staan in verhouding tot mekaar aangesien die leier noodwendig oor baie vermoëns en daaruitspruitende mag beskik. Hierdie mag maak dit vir die leier moontlik om ander te beïnvloed, maar nie om oor ander te regeer nie. Effektiewe leiers beinvloed ondergeskiktes positief op 'n kontinue basis. Dit is dus die gedrag van ondergeskiktes wat volgens Sapre (1996:14) die bewys lewer van 'n bestuurder se effektiwiteit.

\subsection{Chinese perspektiewe op leierskap en menslikheid}

Die Westerse kultuur beskou 'n goeie bestuurder as iemand wat met sekerheid kan bestuur en sy handelinge met rasionele, logiese argumente kan staaf. Die klem word volgens Kam Cheung (1996:2) geplaas op die bestuurshandelinge en die effektiwiteit waarmee dit uitgevoer kan word.

Kam Cheung (1996:2) meen verder dat binne 'n tradisionele Chinese konteks die klem verskuif word na die moraliteit van die leier/bestuurder self - 'n klemverskuiwing wat inslag vind in die manier waarop bestuurshandelinge en leierskap uitgeoefen word. Hier is dus sprake van 'n humanistiese benadering. Moraliteit behels waardeoordele wat inherent tot 'n bepaalde kultuur behoort. Die Chinese kultuur en tradisies is dus 'n logiese beginpunt vir die studie van onderwysbestuur in Hong Kong.

Die Chinese kultuur eis verder dat kennis en vaardighede wat tydens studie ingewin en aangeleer word, toegepas moet word om die gemeenskap te dien. Die belang van die groep word volgens Kam Cheung (1996:7) altyd bo dié van die 
individu (ook die onderwysleier) geplaas. In hierdie verband wys Fung (1990:5) daarop dat Chinese filosofiese denke gebaseer is op drie dinge, naamlik:

- die voortdurende eenheid van alle dinge ('n bio-sentriese kosmologie),

- die noodsaak van 'n waardegesentreerde ontologie,

- die verheffing van die individu in belang van die groep.

Sung (1990:129) beklemtoon die gedagte van 'n algemeen aanvaarde en gedeelde gewete as voorvereiste vir effektiewe samewerking. Hierdie gedagte vind sterk aansluiting by Kam Cheung se siening van die individu wat belangriker is as die groep - 'n siening met onmiddellike implikasies vir onderwysleierskap.

\section{6. 'n Christelike perspektief op Onderwysbestuur en leierskap}

Uit die voorafgaande is dit duidelik dat sieninge oor die mens, die gemeenskap en die rol van die mens binne die gemeenskap sterk figureer in die denke oor Onderwysbestuur en leierskap.

Wanneer sowel die verskillende teorieë (waar onder positivisme en postmodernisme) as die perspektiewe deur die Christen-onderwysbestuurder onder oë geneem word, is dit belangrik dat 'n teorie en/of standpunt geformuleer word wat nie slegs 'n eties-aanvaarbare uitbreiding van sodanige teorie is nie. 'n Christelike siening van leierskap word deur Fowler et al. (1990:157) soos volg beskryf: "Guiding involves a gentleness, an easy way of nudging someone in a certain direction." Om effektief te kan lei, vereis 'n daadwerklike lewensbeskouing en 'n vaste wete van waarheen 'n organisasie op pad is. Volgens Fowler et al. (1990:159) word doeltreffende, duidelike en realistiese doelwitstelling, tesame met 'n bepaalde toekomsvisie as deel van die primêre take van die onderwysbestuurder beskou.

Volgens Thom (1996:11) rig gewetensvrae die volwassene se wetenskaplike denke. Die gewete verwys hierin na die bewuste kennis van regte en verkeerde dade. Thom (1996:12) glo dat die gewete aangewakker word deur Christenskap. Bestuur moet gegrond wees op die gewete, wat nie oorheers word deur skuldgevoelens nie, maar 'n gewete wat empatie, respek, simpatie en regverdigheid vir alle mense voorstaan.

'n Christelike onderwysbestuurder het volgens Thom (1996:18-23) genoegsame selfvertroue, humor en 'n sterk intellek, maar 'n sagte hand. Hy/sy is verder regverdig, waagmoedig, vrygewig, vergewensgesind en aanpasbaar volgens die behoeftes van ander persone. Christenskap word beskou as 'n verenigende teorie met die ideaal van gelyke geleenthede vir almal. Die Christelike gewetens- 
perspektief bied aan die onderwysleier die nodige toerusting om veranderende, uitdagende omstandighede te hanteer.

Beruldsen en Buchanan (1995:12) sê dat die konstante veranderinge waarmee onderwysleiers en organisasies gekonfronteer word, kreatiewe probleemoplossing noodsaak. 'n Kreatiewe leier kan beskryf word as 'n persoon wat gestelde eise beantwoord met gerigte strategieë wat sukses verseker. Verandering behels ten alle tye risiko en onsekerheid, wat die vereiste stel van 'n bepaalde raamwerk wat die aanpassing by sulke verandering sal rig en ondersteun. So 'n raamwerk kan onderverdeel word in komponente soos beplanning, besluitneming, rolverantwoordelikheid, kommunikasie, evaluering, konflikhantering en motivering. Thom (1996:6) sluit hierby aan wanneer hy sê dat die onderwysleier op hoogte moet bly van onderwysontwikkelinge om effektiewe bestuur en leiding op 'n kontinue basis te verseker, terwyl hy steeds basiese waardes en fundamentele lewensbeginsels moet aanhang.

Om moontlike probleme en onsekerhede wat ontstaan as gevolg van veranderende omstandighede te bekamp, stel Thom (1996:9) as oplossing 'n inherente geloof- en waardesisteem. 'n Leier wat volgens 'n Christelike visie lei, sal volgens Mulder (1990:99) elke individu binne sy organisasie ondersteun om sy unieke talente en verborge potensiaal te ontsluit

Leierskapsriglyne binne 'n Christelike raamwerk kan nie werklik afgelei word uit die ekonomiese wêreld waar die hoofdoel die strewe na winsgewendheid is nie. Bybelse riglyne moet volgens Mulder (1990:79) in so 'n leierskapsraamwerk ingebed word. Sekulêre vorme van leierskap is nie noodwendig altyd in stryd met hierdie Bybelse riglyne of Christelike waardes nie. Vergelyk in hierdie verband byvoorbeeld die aspek van positiewe beünvloeding deur leiers (Vedantiese perspektief) en diens aan die gemeenskap (Chinese perspektief), soos vroeër bespreek. Die goeie moet in sowel die sekulêre as in die Bybelse leierskapsriglyne raakgesien word. God gee aan sekere persone die talent om as leiers te funksioneer. Dit is dus die verantwoordelikheid van die bestuurder om, deur middel van hierdie talente, ander mense in sy organisasie, of binne die sosiale orde, te dien. Die onderliggende doel van leierskap is dus diens deur liefde aan ander, nie die retensie van mag of outoriteit nie (Mulder, 1990:90-94). Samevattend stel Mulder (1990:100) dat Bybelse leierskap verstaan moet word in die konteks van die geskape mens as die beeld van God - 'n uitgangspunt wat daarop dui dat die mens volgens Christus se voorbeeld nederig moet lei en nie leierskap moet gebruik as 'n instrument om mag te bekom nie.

'n Kreatiewe leier moet volgens Murphy (1995:13-20) bereid wees om homself in die volgende rolle te plaas: as 'n diener van die gemeenskap, as 'n argitek van organisasiestrukture, as 'n sosiale argitek en as 'n morele opvoeder. MacPherson (1996:3) sê dat 'n ware onderwysleier sy ondergeskiktes lei om krities te dink oor 
die kwaliteit van die kennis wat hul daagliks gebruik. 'n Persoon se kennisbasis en sy kennisteorie stel die riglyne vir wat hy weet, doen en is. Murphy (1995:2730) verskaf die volgende riglyne aan onderwysbestuurders om suksesvol te wees:

- Ontwikkel 'n relevante, uitdagende skoolvisie.

- Verskaf genoegsame hulpbronne om die visie te ondersteun.

- Ontwikkel 'n kommunikasienetwerk om goeie menseverhoudinge binne skoolverband aan te moedig.

- Verskaf genoeg inligting aan onderwysers om goeie besluitneming te bevorder.

- Verskaf indiensopleidingsprogramme om onderwysers professioneel te ontwikkel.

Murphy (1995:23) sê verder dat leiers meer deelnemende bestuursbeginsels moet toepas en meer leierskapsverantwoordelikhede moet delegeer. Vandag word 'n redelike aantal leiers op topvlak vereis wat demokrasie werklik verstaan en waarde daaraan heg. Hulle moet ook weet hoe om outoriteit en vryheid te balanseer binne 'n bepaalde organisasiekultuur. Verder moet onderwysleiers volgens Thom (1996:7) met die nodige entoesiasme, energie en kundigheid reformasie en herstrukturering bevorder in 'n konstant veranderende gemeenskap. Hierdie standpunt van Thom verskaf dan ook die motivering waarom die onderwysleier kennis behoort te dra van strominge in die teorie wat die praktyk ten grondslag lê. Kundigheid met betrekking tot die aard van hierdie strominge verskaf aan die onderwysleier die nodige toerusting om die impak van verandering te kan antisipeer.

Dit is noodsaaklik dat onderwysleiers meer krities raak oor die ontwikkeling van die wetenskap. Dit beteken dat die doel van so 'n leer of teorie eerstens noukeurig bepaal moet word, waarna onderliggende waardes en norme wat deur so 'n teorie gedien kan word, geïdentifiseer moet word. Teorieë moet beskou word as 'n geloofsnetwerk wat saamgestel is uit feite, norme en waardes wat gedrag moet regverdig.

In 'n studie van onderwysbestuur en -leierskap word daar dus kennis geneem van aspekte soos die volgende:

- Die empiries-toetsbare (vergelyk die positivisme).

- Die konteks waarbinne enige ondersoek plaasvind (vergelyk die postpositivisme).

- Individuele sieninge ("stories"- vergelyk die postmodemisme). 
Navorsing in onderwysbestuur en -leierskap vanuit 'n Christelike perspektief verabsoluteer egter nie een van bogenoemde strominge nie. 'n Christelike visie op navorsing en die praktyk van onderwysbestuur hou rekening met empatie, respek, simpatie en regverdigheid

\section{Bibliografie}

BEGLEY, P.T. 1996. Cognitive perspectives on values in administration: a quest for coherence and relevance Educational Administration Quarterly, 32(3) 403-427, Aug

BERULDSEN, A \& BUCHANAN, C. 1995 Reframing leadership: looking at schools from political, structural, human resources and symbolic points of view. (Paper presented at the annual conference of the Australian Council for Educational Administration. Sydney, Australia.)

BOTHA, ME. 1990. Metateoretiese perspektiewe op die sosiale wetenskappe. Potchefstroom : PU vir CHO (In Wetenskaplike bydraes van die PU vir $\mathrm{CHO}$ )

BURGER, W 1994 Postmodemisme: doelgerig of vrolike fuif? 'n Polisieroman en 'n moorddroom Literator, 15(1):59-71, April

DESAI, P.D. 1996. Indigenous perspectives of Educational Management: the Hindu (Vedantic) perspective of Educational Management (Paper presented at the eighth international conference of the CCEA. Kuala Lumpur, Malaysia.)

EVERS, C.W. \& LAKOMSKI, G. 1996. Science in Educational Administration: a postpositivist conception Educational Administration Quarterly, 32(3):379-403, Aug

FOSTER, W. 1993. Postmodern, postmetaphysical and educational administration (Paper presented at the annual meeting of the American Educational Research Association. Atlanta, USA.)

FOURIE, $P 1993$ Televisie, tegnopolie en postmodernisme Communicatıo, 19(1) 2-13

FOWLER, S., VAN BRUMMELEN, H.W. \& VAN DYK, J. 1990 . Christian schooling: Education for freedom. Potchefstroom : PU vir CHO.

FUNG, H. 1990. The spirit of Chinese philosophy. Taipei : Center for Public and Business Administration Education National Chengchi University

GRONN, P. \& RIBBENS, P 1996 Leaders in context: postpositivist approaches to understanding educational leadership. Educational Administration Quarterly, 32(3): 452473, Aug

HOY, W.K. 1996. Science and theory in the practice of educational administration: a pragmatic perspective. Educational Administration Quarterly, 32(3):366-379, Aug

JANGAM, R T. 1970. Logical positivism and politics. London : Sterling.

KAM CHEUNG, W. 1996. Indigenous perspectives of educational management. Is there a need to prepare educational leaders in moral education? An examination of the Chinese traditional thinking on humanity and leadership. (Paper presented at the eighth international conference of the CCEA. Kuala Lumpur, Malaysia.)

MACPHERSON, M. 1996. Indigenous perspectives of educational management: The third watershed in building theories of educational administration: Implications for indigenous policy research and leadership practice. (Paper presented at the eighth international conference of the CCEA. Kuala Lumpur, Malaysia.)

MULDER, C.T. 1990 Biblical leadership in Christian organizations Grand Rapids : Calvin College.

MURPHY, J 1995. Creative leadership (Paper presented at the annual conference of the Australian Council for Educational Administration. Sydney, Australia)

OUWENEEL, W J 1992. Natuurwetenskap en natuurbeskouing. Potchefstroom PU vir CHO. (In Wetenskaplike bydraes van die PU vir CHO.) 
POTCHEFSTROOMSE UNIVERSITEIT VIR CHRISTELIKE HOËR ONDERWYS. 1996. Studiegidslesings: Historiese oorsig. Wetenskapsleerkursus vir dosente. Potchefstroom : PU vir CHO.

RAATH, A.W.G. 1988 Die juridiese positivisme en steun vir die "Freedom Charter". Ide Jure, 21(2):348-356

ROBINSON, V.M.J. 1996. Problem-based methodology and administrational practice. Educational Administration Quarterly, 32(3):427-452, Aug.

ROMM, N.R.A. 1991. The methodologies of Positivism and Marxism A sociological debate. London : MacMillan.

SAPRE, M.P. 1996. Indigenous perspectives of educational management. Educational Management: A Vedantic perspective (Paper presented at the eighth international conference of the CCEA. Kuala Lumpur, Malaysia.)

SUNG, K 1990. A brief history of Taiwan. Taipei : Center for Public and Business Administration Education. National Chengchi University.

THOM P J 1996. Educational leadership worldwide: the Christian conscience factor (Keynote address presented at the eighth international conference of the CCEA. Kuala Lumpur, Malaysia.)

VILJOEN, H. 1988. Spieël, kamer van spieëls; oor postmodernisme en representasie Journal of Literary Studies, 4(4):417-426, Des

WILLOWER, D.J. 1996. Inquiry in Educational Administration in the spirit of the times Educational Administration Quarterly, 32(3):344-366, Aug.

WOLTERS, A.M.L 1992. Die skepping herwin. Bybelse grondslae vir 'n Reformatoriese lewensbeskouing. Potchefstroom : PU vir CHO. (In Wetenskaplike Bydraes van die PU vir CHO.) 